\title{
Podróż do kresu mapy. Destrukcja kartografii jako dekonstrukcja - perspektywa pragmatyczna
}

A journey to the end of the map. Destruction of cartography as a deconstruction - a pragmatic perspective

\section{Świat się skończył w Zdołbunowie}

Zdjęcie przedstawia uczennice szkoły powszechnej w Zdołbunowie na Wołyniu podczas lekcji geografii na świeżym powietrzu (Narodowe Archiwum Cyfrowe - Uczennice szkoły powszechnej w Zdołbunowie).

Schludność i charakter ubioru, brak kajetów, podręczników i narzędzi do pisania, piłka do gry w nogę leżąca pod pierwszym rzędem ławek, bohaterowie drugiego planu: kobieta siedząca za dziewczynkami, jeszcze ktoś, kto nie zmieścił się w lewym kadrze, dwaj chłopcy stojący z tyłu (może to im właśnie przerwano grę?) - te elementy sprawiają, że całość wygląda jak lekcja udawana czy pozowana. A może zostało tu uwiecznione samo sprawdzanie wiedzy, co wyjaśniałoby niezbyt szczęśliwe miny uczennic? Albo opowiadamy już dziewczynkom o geografii bez wymagania od nich żadnego notowania? W każdym razie zdjęcie zapowiada wolność od obowiązków szkolnych, tchnie atmosferą zbliżających się wakacji. Potwierdzałaby to w tym kontekście nieco zaskakująca mapa, przy której stoją nauczycielka z uczennicą, mapa półkuli zachodniej - zdająca się mieć również niejasny związek z tematami nadobowiązkowymi, kanikułą. 
Fotografia należy do zespołu llustrowanego Kuriera Codziennego (IKC), głównego dostarczyciela materiałów, którym dysponuje Narodowe Archiwum Cyfrowe (NAC) dla okresu międzywojennego. Pośród tego zbioru jest jeszcze inne, korespondujące z poprzednim, zdjęcie, datowane na rok 1927. Widać na nim klasę w szkole powszechnej dla dzieci huculskich w Żabiu (obecnie ukr. Werchowyna) - nauczycielka stoi, a dziewczynki i chłopcy w strojach ludowych siedzą, na ścianie wisi mapa Europy opisana alfabetem ukraińskim (Narodowe Archiwum Cyfrowe - Uczniowie szkoły powszechnej dla dzieci huculskich w Żabiu). W samym archiwum znajdziemy kilka przed- i powojennych fotografii przedstawiających wiszące mapy szkolne jako tło różnych wydarzeń. Takie ujęcia tematu są raczej znane i przewidywalne: uczniowie czy nauczyciele pozują na tle map, jeśli więc coś zwraca uwagę, to raczej jakaś nieoczywistość w treści mapy albo w zachowaniu sfotografowanych. Przedstawienie uczennicy przywołanej przez nauczycielkę do mapy (tak jak w Zdołbunowie) pojawia się na zdjęciach udostępnionych przez archiwum bodaj jeszcze tylko dwa razy w fotoreportażu ze szkoły podstawowej w Kalenicach, autorstwa Grażyny Rutowskiej, której spuścizna jest dla zasobów NAC - prezentujących codzienność okresu Polski Ludowej - wciąż mniej więcej tym, czym zbiór IKC dla czasów międzywojennych. Podpisane przez archiwistę datą „marzec 1973” (chyba błędną, bo na tablicy wyraźnie mamy kredą napisane po rosyjsku „marta 1972 goda”) ukazują lekcję rosyjskiego - dziewczyna wskazuje coś na hipsometrycznej mapie Azji (Narodowe Archiwum Cyfrowe - Szkoła podstawowa w Kalenicach).

Wszystkie przywołane zdjęcia są świadectwem praktyki wykorzystania mapy w szkole, którą należałoby próbować umieścić w określonym kontekście: od charakteru instytucji edukacyjnej, projektu oświatowego, w którym te szkoły funkcjonują, przez realne miejsca przez nas oglądane, kwestie językowo-etniczno-społeczne, tak ważne dla Zdołbunowa i Żabia, po zmieniający się program geografii w szkołach pierwszego stopnia. Nie tylko geografii zresztą, skoro oswojenie z mapą odbywa się zanim jeszcze regularne lekcje tego przedmiotu zostają wprowadzone, o czym przypuszczać można choćby z wieku uczniów na zdjęciu ze szkoły huculskiej i programu wiadomości geograficznych dla poszczególnych oddziałów szkoły powszechnej. Zdjęcie Rutowskiej wyraźnie przedstawia z kolei lekcję rosyjskiego. Można by też przyglądać się uwidocznionym na fotografiach mapom - próbować je zidentyfikować. zanalizować projekt świata, jaki za nimi się kryje, odtworzyć ich materialność czy określić proweniencję. Niemniej zdjęcie ze Zdołbunowa niesie ze sobą jeszcze pewien naddatek symboliczny, większy niż w przypadku pozostałych. Mapa Azji, jako pomoc w lekcji rosyjskiego, czy ukraińska mapa Europy, wisząca w szkole na Huculszczyźnie w 1927 roku, nie są zaskoczeniem, czy, używając kategorii zaczerpniętej od Rolanda Barthesa, nie stanowią punctum (Barthes 1996: 46-47), nie wprowadzają dysonansu poznawczego podobnego do mapy półkuli zachodniej wiszącej pod kasztanowcem w Zdołbunowie, ostatnim miasteczku przed granicą radziecką. Zapewne dałoby się 
istnienie tego przedstawienia kartograficznego równie łatwo wytłumaczyć i odtworzyć konteksty, w których funkcjonowało w edukacji powszechnej szkoły przed reformą ministra Janusza Jędrzejewicza, również na terenie województwa, będącego wówczas przedmiotem prowadzonego przez Henryka Józewskiego eksperymentu wołyńskiego (Mędrzecki 2018: 263, 383-384). Nie do pominięcia przy tym byłyby dzieje okrągłych przedstawień kartograficznych od mappae mundi począwszy, długie trwanie procesu, w wyniku którego świat zostaje nam podany, jak pisał Ramón Gómez de la Serna, „niby para jaj sadzonych” (Gómez de la Serna 1979: 85). Obecność tej mapy nie jest oczywista choćby dlatego, że na zdjęciach z archiwum IKC znajdziemy liczne przykładowe kartograficzne pomoce szkolne, mapy historyczne i geograficzne Polski, Europy czy półkuli wschodniej (Narodowe Archiwum Cyfrowe - Mapa Europy i mapy półkul przekazane do szkóf), a nawet własnoręcznie wykonany przez uczniów gimnazjum w Równem plan bitwy pod Wiedniem (Narodowe Archiwum Cyfrowe - Wystawa historyczna. Na ścianie wisi mapa wykonana przez uczniów przedstawiajaca bitwę pod Wiedniem). Mapa półkuli zachodniej pojawia się tylko raz i to od razu w użyciu na „świeżym powietrzu” w krainie, której architektura i infrastruktura jeszcze w 1918 roku skłoniła jednego z oficerów armii niemieckiej do snucia porównań z miasteczkami na preriach Dzikiego Zachodu (Mędrzecki 1995: 108). Być może była więc przedmiotem szczególnej dumy nauczycielki i stąd jej obecność przed fotografem IKC-a? Można powiedzieć, że jest to jeden z anegdotycznych przyczynków do nienapisanej kulturowej historii polskiego szkolnictwa, podobny do tego, od którego swój reportaż Prawo do Wołynia rozpoczął w roku 1936 Ksawery Pruszyński - spotkany gdzieś pod Dermaniem ukraiński pastuch recytuje mechanicznie po francusku początek bajki Jeana de La Fontaine'a (Pruszyński 2000: 123-125).

Zdołbunów położony był kilkanaście kilometrów od Równego, największego miasta województwa wołyńskiego (stolicą był mniejszy Łuck), lecz mimo tej bliskości był od 1925 roku siedzibą osobnego powiatu, który wcześniej nazywał się ostrogskim. To przekształcenie wynikało z kilku powodów, m.in. mający znacznie dawniejszy rodowód miejski i zaczątki kanalizacji jako pierwszy w regionie Ostróg znalazł się po traktacie ryskim właściwie w strefie nadgranicznej, a swoją szybką - prawa miejskie uzyskałw 1903 roku - karierę Zdołbunów zawdzięczał kolei (Mędrzecki 1995: 108, 111)1 Miasteczko było węzłem kolejowym, który nabrał jeszcze większej wagi, gdy 50 kilometrów od niego przeprowadzono granicę. Gdy w II Rzeczypospolitej wprowadzono na całym jej terytorium kolejowy rozstaw normalnotorowy, to w Zdołbunowie na odcinku od strony Ukraińskiej SRR biegł tor szerszy, więc wszystkie pociągi przekraczające granicę w Mohylanych musiały tu stawać już choćby z powodów technicznych. To wrażliwe położenie było także powodem kilku incydentów polsko-radzieckich,

1 Zdołbunów był bodaj najszybciej rozwijającym się miastem regionu, co widać w różnorodnych cywilizacyjnych statystykach, choćby w liczbie położonego bruku i płyt chodnikowych ustępował w pierwszym dziesięcioleciu jedynie nieznacznie stołecznemu Łuckowi. 
z których najsłynniejszym był pożar jednego z radzieckich wagonów w 1937 roku. Transport kolejowy miał także znaczenie dla lokalnego przemysłu - pod miasteczkiem znajdowała się góra Kredowa, będąca dostarczycielem surowca dla pobliskiej cementowni, działającej zresztą do dziś, a obecnie należącej do grupy Dyckerhoff. W herbie Zdołbunowa zobaczyć można zresztą oskard, młotek i klucz nastawny, co dobrze oddaje miastotwórczą rolę kolei i fabryki cementu.

Do Zdołbunowa w niedzielę, 10 września 1939 roku, zjechała kolumna samochodowa Ministerstwa Poczt i Telegrafów, a w niej jeden z urzędników, Zenon Białoszewski wraz z żoną i siedemnastoletnim synem, Mironem. Epizod wrześniowy długo miał status brakującego ogniwa w twórczości pisarza; nieobecność ta była odczuwalna tym bardziej w kontekście przyzwyczajenia czytelników do obcowania z historiami rodzinnymi autora, również tymi okupacyjnymi i przedwojennymi. Ten wymowny brak spowodowany został w dużej mierze znalezieniem się Białoszewskich na terenach zajętych 17 września przez armię radziecką. Główny utwór traktujący o wrześniu 1939 roku, Rajza, ukazał się za życia pisarza tylko w szczątkowej postaci poświęconej pierwszym dniom wojny (1-5 września) jako 1939 w tomie Szumy, zlepy, ciagi. Spowodowało to rozpad reszty tekstu na części i warianty. Końcowa partia opowiadania dotycząca samego wejścia Armii Czerwonej i powrotu bohaterów do Warszawy została opublikowana w dwóch, różniących się od siebie wersjach (w 1985 i 1987 roku), uznawana zaś długo za zaginioną środkowa część, dotycząca podróży z Warszawy do Zdołbunowa, dopiero w 2015 roku w tomie Proza stojaca, proza lecaca (Sokołowska 2015: 414). Niestety, zostaje ona przerwana w pół zdania zaraz po tym, gdy Białoszewski opisuje przyjazd do Zdołbunowa z Równego, gdzie przy marmurowym stoliku w kawiarnio-cukierni bohaterowie zjedli „świetne śniadanie z wymyślnymi rogalikami” i gdzie Miron skorzystał z usług fryzjera i - po raz pierwszy - golibrody:

Ostatecznie wyładowaliśmy się w Zdołbunowie. W ostatnim miasteczku na wschód; najbliższa była Szepietówka - już rosyjska. Ze Zdołbunowa Ministerstwo Poczt sprowadzało sobie wędliny dla pracowników. Do nas też przychodziły. Opłacało się, bo hurtem i taniej. Pamiętam naklejki pocztowe z egzotycznie dalekiego Zdołbunowa. I teraz nagle tu jesteśmy. I to na łasce. W tym niespójnym, domkowo-zielskowym miasteczku. (...) Myśmy zamieszkali u młodego sędziego, pana Szpyta, który jeździł jeszcze samochodami na rozprawy. Jego domek stał w sadzie, między... (Białoszewski 2015: 236).

Opowiadanie w obecnej formie pozbawione jest zapisu dotyczącego sześciu dni między niedzielą 10 a nocą z 16 na 17 września. Nie wiemy, czym zajmował się Miron w Zdołbunowie przed wejściem Sowietów. Nie możemy też być pewni, co oznaczała owa krótka charakterystyka miejsca („niespójne”). Romuald Wernik, opisujący z perspektywy lat i emigracji w nostalgicznym tonie miasteczko swojego dzieciństwa, 
podkreśla widoczne kontrasty między, położoną za torami, jednolitą osadą domków kolejowych z dachami z blachy a miasteczkiem wyrosłym na terenie dawnej wsi z jednej strony, a z drugiej z przylegającą do Zdołbunowa od południa ukraińską wsią Zdołbica, która zaczynała się po drugiej stronie ulicy Granicznej (Wernik 2001: 14, 20). Opisując nowe budowle wzniesione w dwudziestoleciu (starostwo, magistrat, szkoła, stadion, kościół), wyraża się w znamienny sposób o reszcie zabudowy: „tu i ówdzie wyrosło kilka nowoczesnych domów", jeśli dodamy do tego gimnazjum w stylu określonym jako empire, to efekt mógł być osobliwy (Wernik 2001: 52). Być może to kryje się za określeniem „niespójne”, trudno przecież zakładać, że to zielska są niespójne z domkami, albo że chodzi tu o kontrasty społeczne, kulturowe czy etniczne, skoro już wcześniej w podróży ujawniły się one z całą mocą.

Rajza ma więc postać wymuszonego tryptyku, tym bardziej frapującego, że ułamkowa forma (urwanie drugiej części, powtórzenia), świadcząca o jej trudnych dziejach, o których wiemy w gruncie rzeczy niewiele, jeszcze efektowniej wyraża wrześniową traumę. Opowiadanie jest swoistym suplementem do Pamiętnika z powstania warszawskiego, czy może należałoby powiedzieć: prequelem, wyraźnym w opublikowanej w Szumach, zlepach, ciagach pierwszej, warszawskiej części, gdzie opisane zostaje m.in. bombardowanie domu na ulicy Ogrodowej, i w zakończeniu. Opowieść o rajzie zostaje domknięta na skrzyżowaniu Chłodnej i Żelaznej, dokładnie w tym samym miejscu, gdzie powstanie zastaje narratora Pamiętnika. Podobną łączność pomiędzy tekstami stanowią wtręty, będące refleksją nad spełnianiem się polskiej historii czy nad wymiarem codziennym wojny (Wrzesień 1939 w samym Pamiętniku był z kolei ukazany jako prefiguracja Sierpnia i Września 1944, co oczywiście nie jest jakimś oryginalnym konceptem Białoszewskiego). Jednocześnie, nawet w jej niepełnej postaci, można Rajzę czytać łącznie jako „panoramę z Apokalipsy” (Białoszewski 2015: 231). Nazwa tego gatunku, często odnoszona przez pokolenie wojenne do przeżyć wrześniowych i okupacyjnych, zostaje użyta do konkretnego wspomnienia z trasy ucieczki („mijanka ze Sławojem przy Bugu pod murami Brześcia, w tłoku, kurzu i żółtym słońcu"; Białoszewski 2015: 231), ale jeśli bliżej przyjrzeć się narracji, to właściwie jest ona ciągiem zdarzeń o intensywnej wymowie symbolicznej, na różny sposób wyrażających koniec świata II Rzeczypospolitej, włącznie ze świetnym śniadaniem, wymyślnymi rogalikami i postrzyżynami w Równem. Trudno zatem powiedzieć, czy rzeczywistym środkiem ciężkości Rajzy pozostaje wejście armii ZSRR, ale z punktu widzenia urzędników w Zdołbunowie to wejście jest właściwym końcem Polski, po którym bohaterowie czekają już tylko z pewnym zniecierpliwieniem na kapitulację Warszawy, umożliwiającą im powrót do domu (a w trakcie podroży powrotnej Miron ogląda już świat po apokalipsie, co nie znaczy, że epizody w tej części nie są równie wymowne). Rozpoczęcie trzeciej części opowieści od takiego właśnie punktu zwrotnego robi wrażenie przemyślanej decyzji, zwłaszcza że pojawieniu się wojska radzieckiego w miasteczku towarzyszy następująca scena: 
W ostatniej siedzibie ministerstwa poczt panował zorganizowany popłoch. Na każdej kondygnacji przy każdym piecu siedział na krzesełku urzędnik i ładował po kolei do ognia papiery, dokumenty, mapy ze sterty obok. Inni zbierali jeszcze, co się zdąży, i te sterty dopełniali. Tak w jednej chwili obracali w popiół dwadzieścia lat swojej pracy, bo były to ich własne dłubaniny.

Mój ojciec kreślił mapy telegraficzne. W ostatnim okresie napięcia robił to i nocami. I my z mamą ojcu pomagaliśmy. Dyktowaliśmy miejscowości. Teraz to szło w ogień.

Te mapy były wykonywane tuszem na krochmalonej surówce. Mamie i pani Jance Skowrońskiej żal się zrobiło surówki. Złapały ze trzydzieści map

- My to wypierzemy i będzie na koszulki, na chustki.

Natychmiast wyniosły balię do ogródka, wrzuciły do balii mapy i zaczęły prać. Co wyprały, wieszały na sznurze między drzewami. Świeciło słońce. Tarki chrobotały. Piece dymiły. Zrobiło się popołudnie i czołgi już przejeżdżały ulicą. Ulica była za siatką. Panowie urzędnicy przy piecach siedzieli dalej przy krzesełeczkach, tylko szybciej podkładali. Mama i pani Janka zawiesiły już dwa czy trzy rzędy wypranych map. Ulicą szli sowieccy żołnierze i śpiewali:

- „Jesli zawtra wajnaa....

Urzędnicy i urzędniczki nie tracili humoru.

- No, trzeba będzie pozdejmować krawaty, bo to źle widziane.

Pani Janka romansowała z panem Romanem O., który miał żonę, tyle że nie tu. Jankę S. nazwali jego sowiecką żoną (Białoszewski 2015: 237-238).

Mamy tu do czynienia ze zdarzeniem ostatecznym, momentem, gdy w Zdołbunowie poniekąd kończy się apokalipsa i stary, choć działający w wyjątkowych warunkach, porządek zostaje zniesiony. Ministerstwo Poczt i Telegrafów przechodzi w stan przyspieszonej samolikwidacji. Koniec II Rzeczypospolitej oznacza koniec jej urządzeń i instytucji, efekty dwudziestoletniej pracy urzędników muszą zmienić się w popiół, nie mogą dostać się w niepowołane ręce. Jednocześnie troskliwy gest mamy i pani Janki, ocalający materialność części dokumentów, zapowiada kulturę okupacyjnego erzacu i otwiera etap trudnej okupacyjnej normalizacji, który będzie głównym tematem trzeciej części Rajzy. Wyprane mapy pod postacią bawełnianej surówki stają się częścią strumienia przemieszczających się w warunkach wojennych w przyspieszonym tempie przedmiotów, krążenia rzeczy. Nagła nowa użyteczność, bezużytecznych w tym momencie, map telegraficznych i pocztowych ustanawia paradoks niecodziennej codzienności (Rodak 2009).

W nietraceniu humoru przez urzędników i urzędniczki można zobaczyć robienie dobrej miny do złej gry czy jakiśs rodzaj naiwności, ale jest w nim też zapewne zadowolenie, że zdążyli na czas z likwidacją roboty, a może ulga, że się już skończył ten nadzwyczajny stan w wyjątkowym miejscu urzędowania w Zdołbunowie. Tych końców świata jest zatem więcej, bo przecież mapy dobiegają swojego kresu 
w momencie końca tego świata, w którym funkcjonowały i który przedstawiały, ale dzieje się to na końcu tejże mapy, u wschodnich rubieży świata przedstawionego. Zostaje to zaakcentowane poprzez uruchomienie kartograficznej metafory w opowiadaniu Białoszewskiego już wcześniej, gdy pisze on o samym momencie wyjazdu z Warszawy: „nie zdawaliśmy sobie sprawy, że przed nami, za nami idzie drugi ciąg; żywa mapa... i do tego historyczna" (Białoszewski 2015: 225). W wyniku trzęsienia czasu mapa ożywa, ale przechodzi do historii, staje się przedstawieniem stanu przeszłego. Uzmysłowienie sobie, że samemu jest się częścią jakiejś mapy dogoniło narratora w Równem:

- Równe.

- Wysiadać.

No tak. Ale to koniec mapy.

Zdołbunów ostatni na wschód. Postój dłuższy. Tu. I jedziemy do Zdołbunowa. Więc jedziemy na sam koniec. Dalej się nie da. Bo gdyby się dało, tobyśmy gnali jeszcze dalej, i jeszcze dalej. Teraz już pojąłem, że koniec z Polską. Koniec szybciutki (Białoszewski 2015: 235-236).

Dotarliśmy do bieguna rajzy. „Nazwa nie za szlachetna, ale to z ironii, przezwisko” - wyjaśniał w części pierwszej opowiadania narrator (Białoszewski 2014a: 56).W komentarzu do tytułu drugiej części dodawał: „To słowo było w Polsce użyte jednorazowo. Na okoliczność wędrowania czy uciekania przed Niemcami na wschód we wrześniu 1939 roku" (Sokołowska 2015: 414). Słowo jest oczywiście pochodzenia niemieckiego, potoczne, Bronisław Wieczorkiewicz dla gwary warszawskiej wieku XIX podaje znaczenie neutralne „droga, podróż" (Wieczorkiewicz 1966: 360). Wydaje się, że w języku mieszkańców stolicy mogło przybierać odcień ironiczny. Do rozstrzygnięcia pozostaje, czy działo się to już wyraźnie wcześniej, przed II wojną światową, czy to stało się pod wpływem zastosowania go do określenia wrześniowego - chciałoby się powiedzieć - bieżeństwa, np. w jednym z wczesnych tekstów Marka Hłaski słowo to zostanie użyte mniej więcej w znaczeniu, które później określać się będzie mianem „gigant” (Hłasko 2016: 158). Rajza wrześniowa Białoszewskiego jest nietypową podróżą przez przestrzeń, próbującą uciec przed swoim przeznaczeniem, po mapie, przekształcającej się w mapę historyczną, z pakami pełnymi planów pocztowych, które trzeba spalić lub poddać recyklingowi.

\section{Wojna i mapa}

W Pamiętniku z powstania warszawskiego Mirona Białoszewskiego słowo "mapa” pojawia się bodaj raz, w kontekście walk zmieniających odczuwanie przestrzeni w mieście: 
Nigdy Warszawa - chociaż jest cztery razy większa niż wtedy - nie wydawała się taka skomplikowana i duża, bez końca. Odległości - rozciągnięte. Układy i podziały przetentengowane, przełuskane, wykopane i przełapane w drobną siatuchnę. Teraz to mnie rozczula, że byłem na zbiegu Kruczej-Pięknej-Mokotowskiej, a od placu Politechniki strzelali tamci - i to się wydawało i czuło daleko. (...) Mimo woli człowiek przesuwał całą topografię frontu. Brzeg praski wydawał się w ogóle jak z innej mapy. Hitlerowcy z lornetkami na wielkich drzewach w zoo i front wschodni na Żeraniu - mitem, który się co prawda objawiał, ale jako druga i trzecia rzeczywistość. Co znaczą jednak - bo to jest chyba głównym powodem - przedziały i odległości psychiczne. Przecież o to samo chodziło w powstaniu żydowskim (Białoszewski 2014b: 54).

„Jak z innej mapy” to potoczne porównanie wyrażające nieprzystawalność sytuacji po obu stronach rzeki, właściwie dwóch odrębnych miast. Mapy kolejnych rzeczywistości wskazują na różnicę skali między porównywanymi obszarami, ale także z konieczności inne byłyby przedmioty, które na takich hipotetycznych planach winny się znaleźć. W przypadku pierwszej rzeczywistości będzie to mapa enklaw, w których ruch odbywa się „deptakami elizejskimi” - „i rury, i dziury, i piwniczki, i krętaninki” (Białoszewski 2014b: 164) - zatem szlakami przez podwórka, przejścia między barykadami, okna, przebite mury, czyjeś legowisko w korytarzu, a komunikacja pomiędzy enklawami jest utrzymywana z kolei siecią kanałów; ta mapa obejmowałaby także obiekty, które jeszcze stoją, choć często są już nadpalone albo już stają się ruiną oraz gruzy; wreszcie mapą pierwszej rzeczywistości byłby plan w mikroskali: labiryntu piwnic, które szczególnie w opisie podziemi na Rybakach przyjmują cechy podziemnego miasteczka, poszczególnych kamienic, mieszkań, schodów, filarów, wychodków i miejsc zaopatrywania się w wodę.

Świadectw myślenia mapą - mimo jednokrotnego tylko użycia samego słowa - mamy w Pamiętniku wiele. Często znajdujemy się w sytuacji kartograficznego przełączania się między opisywanymi rzeczywistościami, niekiedy narrator przypomina sobie o perspektywie lotu ptaka i np. szereguje swoją wiedzę o powstaniu na przedmieściach w porządku planu, „północ - południe - wachlarzykiem”, od Żoliborza przez Powązki, Wolę, Ochotę, Mokotów do Czerniakowa (Białoszewski 2014b: 208). Ład kartograficzny istnieje przede wszystkim na tym odgórnym poziomie, w spojrzeniu na całość planu miasta, które jest tylko uogólnionym spojrzeniem synchronicznym, co w przypadku dynamicznie zmieniającej się rzeczywistości, jak ta powstańcza (włączając ruch Armii Czerwonej), prowadzi tylko do przedstawienia umownego w rodzaju podsumowania narratora Białoszewskiego: „Powązki - tu wiem mało (...) Wola - wiadomo co" (Białoszewski 2014b: 208) lub przypisów do zdań ogólnych. Mapy analogowe, które mają ambicję oddać całokształt dwumiesięcznych zdarzeń w mieście na jednym arkuszu, muszą poradzić sobie z tą diachroniczną trudnością, w praktyce rozwiązania te są na granicy czytelności, jak dobrze widać 
w przypadku, skądinąd użytecznej, Mapy powstania warszawskiego pod redakcją Piotra Kamińskiego, pełnej kolorów, dat i informacji (Mapa powstania warszawskiego 1 VIII-2 X 1944, wyd.2012). W warstwach niższych porządek ten cechuje jeszcze większa kruchość, zmienność, której tempo nie pozwala ustabilizować się żadnemu obrazowi na dłużej. Jako przykład przewagi trasy nad mapą (kategorie zaczerpnięte od Michela de Certeau), życiowej konieczności ruchu w okolicznościach wojennych, analizowała dzieło Białoszewskiego Katarzyna Szalewska. Nazwała Pamiętnik „bodaj najbardziej wyraźnym manifestem niemożności zaistnienia porządku retorycznego w sytuacji zagłady towarzyszącego mu porządku kartograficznego" (Szalewska 2017: 133), nieskładanie się obu tych warstw (ruchu i trasy z mapą i miejscem) wywołujące rozpad fabuły jest związane z trudem „nieustannego lokowania siebie i innych uczestników tej ekstremalnej praktyki przestrzennej, jaką jest udział w powstaniu" (Szalewska 2017: 134). Badaczka wskazuje na analogiczne narracje w innych tekstach dotyczących wojny.

Wojna niewątpliwie nie tylko znosi dany porządek kartograficzny, likwidując świat, który za nim stoi, ale wywołuje trwały kryzys materialno-semantyczny związany ze stanem wyjątkowym, jaki zaprowadza. Ciągła zmiana związana z dynamiką frontów, ale także polityką władz okupacyjnych na danym terenie powoduje płynność i szybką dezaktualizację nanoszonych informacji. Mapy są jednocześnie niezbędne do prowadzenia działań zbrojnych, więc sytuacja wymaga, by je produkować, ulepszać, wykradać, chronić. Istotą wojny jest permanentny deficyt kartograficzny dotykający zarówno cywilów, jak i wojsko, w tej samej mierze osoby i instytucje. Historię drugiej wojny i okupacji da się zapewne opowiedzieć poprzez dzieje braku mapy, począwszy od legendarnych kłopotów z zaopatrzeniem w mapy wojsk polskich walczących we wrześniu 1939 roku, co potwierdzają we wspomnieniach oficerowie i wyżsi dowódcy, choćby generał Władysław Anders. Niedobory te próbowano zaspakajać tym, co było, np. broniący Warszawy używali zwykłych, „kolorowych” planów miejskich zabranych ze składu Spółdzielni Inwalidzkiej (Sobczyński 2009: 10-11). Kazimierz Wyka w Pamiętniku po klęsce utrwalił obraz żołnierzy września zrywających pośpiesznie w odwrocie mapy ze szkolnych ścian (Wyka 2011: 11).

W 1940 roku Związek Walki Zbrojnej utworzył składnicę map potrzebnych do działań podziemia, pochodzących z zachowanych zasobów, zakupów, zrzutów i w różny sposób wydobytych od Niemców. Ponieważ jednak te źródła okazały się niewystarczające w kontekście narastających zmian, w początkach roku 1943 powołano Sekcję Geograficzną Komendy Głównej AK „Schronisko” (Krassowski 1981; Sobczyński 2000 171-178). Niespełna 200 osób zajmowało się profesjonalnym opracowaniem i drukowaniem map w odpowiedzi na plany akcji „Burza” oraz przewidywanego wybuchu powstania w Warszawie. W oparciu o cztery arkusze Wojskowego Instytutu Geograficznego z lat 1931 i 1934, obejmujące miasto i jego najbliższą okolicę w skali 1:25000, opracowano nową mapę - przeprowadzono aktualizację w terenie, naniesiono ważne 
z punktu widzenia militarnego informacje o obiektach obsadzonych przez wojska niemieckie czy gruzach². Szczególnie ta część pracy nad mapą była niebezpieczna z uwagi na zaangażowanie większej liczby ludzi pracujących w podzielonym na sektory mieście, fizyczne zbliżenie do obiektów pilnowanych przez Niemców, jak również potrzebę robienia - przynajmniej w ograniczonym zakresie - notatek w trakcie wizji lokalnej. Ze względów bezpieczeństwa nie brano ze sobą nawet fragmentów map, a niezbędne rzeczy rysowano czy pisano na gazetach (Krassowski 1981: 49-50).

W roku 1963 w serii wydawnictwa Ministerstwa Obrony Narodowej „Druga Wojna Światowa - Bohaterowie, Operacje, Kulisy” (tzw. serii "Z Żółtym Tygrysem” od koloru logotypu z tym zwierzęciem na okładce) wyszła książeczka Akcja "Plan Warszawy”. Jej autorem, używającym pseudonimu Andrzej Konrad, był generał Jerzy Fonkowicz, który w trakcie wojny pełnił m.in. funkcję szefa wywiadu Gwardii, a później Armii Ludowej - w PRL z kolei do roku 1968 pozostawał w służbie czynnej Wojska Polskiego. Nie jest dla mnie jasne, dlaczego trzy książeczki wspomnieniowe w tej serii opublikował nie pod swoim nazwiskiem, skoro równocześnie jako „Jerzy Fonkowicz” wydawał w latach sześćdziesiątych inne publikacje dotyczące swojej wojennej przeszłości. Autor przedstawia w książce procedurę rozpoznawania sił wroga na terenie Warszawy, która równocześnie miała służyć unacześnianiu mapy miasta na użytek działań własnych i, jak miał nadzieję autor, Armii Czerwonej. Bojowcy GL mieli przeprowadzić całą akcję w 1943 roku, w tym samym mniej więcej czasie, co Armia Krajowa dla własnych potrzeb. Oficjalna historia kartografii podziemia komunistycznego w Polsce i wspomnienia kierownika fabryki map AL Teodora Naumienki nic nie mówią o tej akcji (Naumienko 1978: 32-33; Sobczyński 2000: 178-179). Niewykluczone, że była ona w większej mierze sterowana przez wywiad radziecki, albo że została wyolbrzymiona przez dowodzącego nią Fonkowicza. Czy wreszcie, że opisując ją, wzorował się on na czynach i działaniach AK. Wszystkie te opcje nie stoją ze sobą zresztą w sprzeczności.

Treścią Akcji „Plan Warszawy” są przygody gwardzistów w trakcie prób pozyskiwania i przekazywania zdobytych informacji w typowej dla tej serii poetyce i aurze ideowej (Franz 2011: 110-114), niemniej jednak z przedstawionych zdarzeń - wbrew hagiograficzno-propagandowej tonacji - wyłania się niejednoznaczny obraz rzeczywistości. Jeśli lotnictwo radzieckie, w przeciwieństwie do aliantów zachodnich, dokonywało nalotów chirurgicznych, to skąd bierze się strach, brak zaufania i niewiedza nie tylko warszawiaków (ale i narratora!) w trakcie jednego z sowieckich bombardowań Pragi. Nie da się tych odczuć sprowadzić do niepewności, czy lotnicy radzieccy mają już dane kartograficzne dostarczone im przez wywiad GL (podrozdział Nocny alarm). Poza tym bojowcy mają bardzo dużo szczęścia wobec liczby drobnych i większych błędów konspiracyjnych, które wciąż popełniają, np. dozorca, który przybywa

2 W 2004 r. dokonano reprintu wszystkich czterech arkuszy mapy: Konspiracyjna mapa Warszawa „BOM”, 1:25 000. 
do administratorki „Wandy”, żeby obejrzeć z nią mapę Europy Wschodniej przewraca się na leżącym na podłodze naboju, który wypadł gwardzistce z szafy. Fonkowicz stara się osadzić całość w realiach topograficzno-obyczajowych okupowanej Warszawy, co stanowi może najbardziej wiarygodną warstwę książeczki - w przypadku codzienności kartograficznej oznacza to zarówno wspomnienie o łatwej dostępności przedwojennych planów miasta (oraz ich nieprzydatności do celów militarnych), jak i o owej praktyce oglądania indywidualnie czy wspólnie z sąsiadami map Europy. W przypadku tego autora chodziło o próbę uzgodnienia wiedzy przekazywanej z różnych źródeł z reprodukowanym obrazem świata, ze szczególnym zainteresowaniem dla sytuacji na froncie wschodnim (Konrad 1963: 9, 70-71). Potrzeba śledzenia teatru zmagań wojennych jest charakterystyczna dla wszystkich wojen i podobne sceny kartograficzne będą należały do repertuaru realiów w przypadku innych obchodzących nas konfliktów. Adam Ważyk w Mitach rodzinnych, powieści rodzinno-rozwojowej rozgrywającej się w drugiej dekadzie XX wieku, przedstawi nam takie deliberacje familijne nad mapą Europy w trakcie I wojny światowej - mimo fałszowania komunikatów, bohaterowie starają się czegoś dowiedzieć i spędzają kwadrans po obiedzie na kontrolowaniu chorągiewek na mapie, dla której znajdują specjalne miejsce w kącie sypialni (Ważyk 1956: 49-50).

Po wydaniu uaktualnionej Konspiracyjnej mapy Warszawy pracownicy „Schroniska" prowadzili w dalszym ciągu prace nad opracowaniami tematycznymi w jego ramach, m.in. planem sieci wodociągowo-kanalizacyjnej, które nie zostały jednak ukończone przed latem 1944 roku. Powstanie warszawskie można więc traktować jako ukoronowanie podziemnej działalności kartograficznej - pytanie, w jakiej mierze działania te przełożyły się na użyteczność powstałych map w powstaniu (jak również w całej akcji „Burza”). Duża część nakładów została zniszczona w trakcie walk w składnicach, za wyjątkiem tych, które znalazły się w największej z nich znajdującej się na ulicy Krochmalnej, ale te z kolei zostały wydobyte dopiero po wojnie. Jednocześnie na początku powstania "Schronisko” podzieliło się na dwie grupy zaopatrujące powstańców w potrzebne materiały: pierwsza działała do 17 sierpnia na terenie składnicy na Franciszkańskiej na Starówce, druga zaś operowała w Śródmieściu przynajmniej do początków września (po czym oddelegowano jej członków do konkretnych oddziałów).

Oczywiście to tylko ułamek wojskowej części historii polskiego używania map w czasie II wojny światowej. O ile jednak ma ona swoją literaturę przedmiotu, to słabiej obecny w badaniach pozostaje cywilny obieg kartografii: oficjalna produkcja planów, prowadzona za zezwoleniem okupanta, czy propaganda przedstawiająca Niemcy wygrywające na wszystkich frontach, podczas gdy jest dość dowodów materialnych, że był on składnikiem wojennej codzienności (np. przywołane wspomnienia Fonkowicza, liczne zdjęcia i same artefakty, mapy). Odrębnym zagadnieniem jest udział polskich kartografów w opracowaniu planów zarówno tych legalnych, jak i konspiracyjnych. 
W przeciwieństwie do Pamiętnika z powstania warszawskiego Białoszewskiego, w Rojstach Tadeusza Konwickiego, powieści osnutej wokół udziału pisarza w partyzantce antyradzieckiej na Wileńszczyźnie przełomu 1944 i 1945 roku, słowo „mapa” pada wielokrotnie. Rzeczywiście trudno sobie wyobrazić wojnę partyzancką bez mapy, charakterystyczne jednak, że jest ona nieodłącznym - „niemalże homeryckim" (Sobczak 2017: 29) - atrybutem dowódcy oddziału, plutonowego Kwiatka, zewnętrzną oznaką jego autorytetu, o czym narrator pisze bezpośrednio (Konwicki 1992: 144). Jedynie na początku zostaje wspomniany kapral Zew sprawdzający drogę z mapą, ale to on prowadzi grupę nocą do oddziału (Konwicki 1992: 26). Później w każdej wolnej chwili dowodzący Kwiatek rozkłada mapy i je studiuje, szukając najdogodniejszej drogi czy medytując nad kolejnymi miejscami postoju. Gdy się z nimi rozstaje, pożyczając je podkomendnemu Sułtanowi wysłanemu w celu rekwizycji żywności, dochodzi do pomyłki (nie jedynej w powieści, ale jedynej z mapami w roli głównej). Zamiast „zbombić gada”, sprzyjającego władzy sowieckiej, grupa napada na rotmistrza Orzeszkę, ważną figurę w miejscowym podziemiu, którego folwark znajduje się po sąsiedzku do zaścianka renegata. Chlubiący się swoim „nowostrojskim pochodzeniem", fachowo obsługujący nóż czy sztachetę od płotu, przedstawiciel przedmiejskich nizin wileńskich, Sułtan, nie potrafi zrobić użytku z mapy (Konwicki 1992: 156). Podobnie jak należący do oddziału chłopi, którzy „nic nie rozumieli. Nie znali map, nie wiedzieli nigdy, gdzie się znajdujemy. Kwiatek umyślnie trzymał ich w tej niewiedzy" (Konwicki 1992: 86). Mapa jest tu rekwizytem obciążonym klasowo, służącym dowódcy nie tylko do orientacji, ale również do manipulowania resztą oddziału. Jak pisze Kornelia Sobczak, „umiejętność posługiwania się mapą jest przywilejem wileńskiego inteligenta Polaka, który utrzymuje w topograficznej niewiedzy przymusowo zwerbowanych chłopów" (Sobczak 2017: 29). Ostatecznie jednak jej użyteczność wobec skomplikowania sytuacji staje się problematyczna: „Kwiatek coraz niespokojniej czytał mapy, coraz cieńsze niteczki wybierał do następnego marszu" (Konwicki 1992: 163), i musi ona skapitulować przed wolą zaprzestania walki przez członków oddziału - dla samej czynności powrotu do domu okazuje się niepotrzebna.

Ryszard Kiersnowski, którego osoba, wraz z plutonowym Wrzosem, stanowiła główny prototyp plutonowego Kwiatka (Kiersnowski 2007: 173), napisał po latach wspomnienia z okresu walki partyzanckiej na Wileńszczyźnie, w której zamieścił polemikę z warstwą ideową Rojstów. Przy tej okazji przypomniał własne opowiadanie Kościelna Góra, pierwotnie opublikowane przez „Tygodnik Powszechny” w 1946 roku, a przedrukowane po latach również częściowo, jak można sądzić, w celu skontrowania powieści Konwickiego (napisanej rok później, a wydanej po raz pierwszy dziesięć lat po opowiadaniu Kiersnowskiego, w 1956 roku). Już choćby ze względu na podobieństwo motywu konfrontacji ze śladami powstania styczniowego ta konfrontacja jest wyraźna, ale w przedrukowanym tekście Kościelnej Góry pojawia się również polemiczny wobec 
Rojstów przypis (Kiersnowski 2007: 194). Co najbardziej interesujące, w opowiadaniu dawnego dowódcy pojawia się mapa w ręku prowadzącego oddział:

Mapa nie zawiodła, kompas dobrze wskazał. To ta biała plamka na ogromnej plamie puszczy. „Puszczyk” siedzi na ławie oparty o ścianę i patrzy, patrzy na mapę. Mapa jest najbardziej podniecającą książką najciekawszą lekturą. Zna ją na pamięć, zna każdy szczegół, każdą literkę, każdą kreskę. To wszystko takie ważne, takie ogromnie ważne; to ma wagę życia i śmierci.

-Gospodyni, a poświecić mi tu bliżej łuczywem.

Czerwony blask na zielonej powierzchni lasów. Wioski gdzieś u brzegów jak wielkie, czarne żuki z długimi wąsami napisów. A pośrodku zielono, zielono, zielono. Błękitne niteczki rzek, delikatna siatka dróżek i tryb leśnych... ale to nieprawda, te ścieżki idą zupełnie inaczej. Tam trzeba być, trzeba to widzieć. Kartograf nigdy tam pewnie nie dotarł, nie sprawdził, jak się idzie z Poszyłeń na Długą Wyspę ani z Aszkałejt do Kiermasyna (Kiersnowski 2007: 193).

Trudno o obraz bardziej współgrający z kompulsywnie wpatrującym się w mapę Kwiatkiem z Rojstów, a jednocześnie monolog wewnętrzny bohatera podaje w wątpliwość prawdę kartograficzną, że w świetle ludzkiego doświadczenia każda mapa jest przekłamaniem. W następującym bezpośrednio po Kościelnej Górze współczesnym komentarzu, autor przyznaje się, że prowadził oddział do tego miejsca nie tylko z powodów praktycznych, ale i z ciekawości. Co więcej, „był jeszcze drugi punkt na tej samej mapie, który budził we mnie podobną, a nawet większą ciekawość. Była to Polacka Polana w północno-zachodniej części puszczy, niedaleko od Inklaryszek. Przy nazwie tej umieszczony był krzyżyk i napis «Mogiła Powstańców 1863». Musiałem tam dotrzeć" (Kiersnowski 2007: 195). Mapa zatem, choć tak niedoskonałym odbiciem będąca, uwodzi wyobraźnię dowódcy, każe mu manipulować ludźmi i ostatecznie rządzi losami oddziału. W innym miejscu książki Kiersnowski wspomina o objawach niepokoju „chłopców wiejskich”, którzy chcieli już „odejść do tych Turgiel i Talei, ale nie wiedzieli, jak to zrobić, bo tylko «Wrzos» i ja mieliśmy mapy, a zresztą nawet mając mapy, nie potrafiliby ich wykorzystać” (Kiersnowski 2007: 178). W świetle powyższych świadectw trudno nie przyznać Kiersnowskiemu racji, gdy pisze o Rojstach, że „sporo epizodów przedstawił przecież Konwicki w sposób zbliżony do prawdy" (Kiersnowski 2007: 173). Na pewno w tych tyczących się kartografii partyzanckiej, wbrew przekąsowi plutonowego Puhacza, jego wspomnienia i powieść byłego podkomendnego, Bobra, mówią rzeczy zbieżne.

Mapa stanie się rekwizytem w innych dziełach Konwickiego poruszających problematykę wojenno-partyzancką, choćby w Senniku współczesnym, widzimy ją także na ekranie w Zaduszkach. W sekwencji wojennych wspomnień Wali (Ewa Krzyżewska), w których znajdziemy trochę podobieństw do zdarzeń i dialogów z Rojstów, 
dostrzeżemy, i to już w pierwszej scenie, mapę - gdy bohaterka wchodzi do domu, w którym zgromadzony jest oddział, z dzisiejszej perspektywy terminologicznej należałoby powiedzieć, żołnierzy wyklętych, jego dowódca Derkacz (Mieczysław Voit) trzyma w ręku częściowo złożony plan. Z kolei Krajobrazy, proza napisana u początków drogi pisarskiej, zaczyna się następująco:

Mój przyjaciel, Stefan Kornetowicz, szedł z Dworca Wileńskiego na Dworzec Zachodni. Nie było to łatwa droga, tym bardziej że Stefan nie znał dobrze Warszawy. Co prawda przy boku kolebał się celuloidowy mapnik z postrzępionym planem miasta, lecz Stefan nie sądził, aby mógł z niego skorzystać w szarym cmentarzysku za Wisłą (Konwicki 2011: 268)

Konwicki będzie wracał w swoich wczesnych próbach literackich do motywu pierwszej wizyty w zniszczonej Warszawie, przetwarzał własne doświadczenia, choćby w niedokończonej powieści z lat 1947-1948 pod tytułem Nowe dni. Kiersnowski, z którym dotarł pisarz do zrujnowanego miasta w 1945 roku, napisał: „Wchodziliśmy w ten labirynt ścian i gruzów, przekopanych rowów i nierozebranych jeszcze barykad, i zaczynaliśmy dostrzegać inne proporcje dopiero co skończonej wojny, wobec których nasza Puszcza Rudnicka mogłaby się zdawać zacisznym ogrodem" (Kiersnowski 2007: 168). Mapa puszczy nie była już im jednak potrzebna, a z planu Warszawy nie było jak skorzystać

\section{Koniec kartograficznego świata}

Rajza Mirona Białoszewskiego opowiada historię końca pewnego kartograficznego świata, a nawet można powiedzieć początku jego końca. Zniszczenie specjalistycznych map należących do instytucji odchodzącego w niebyt państwa to jedno, drugie zaś to niemożliwa próba wymazania jego kształtów, przedstawień z pamięci, myśli i wyobraźni ludzkiej czy niemożność fizycznej likwidacji pozostałych po nim różnorodnych map i planów. Wrzesień 1939 jest także kolejnym etapem głębokich przeobrażeń w obrazie świata związanych z II wojną światową, dla wielu ludzi pamiętających jeszcze zmiany sprzed dwudziestu lat była to już w ich życiu druga podobna rewolucja. W Cytatach, cyklu otwierającym, wraz z Donosami, drugi tom prozatorski Białoszewskiego, Donosy rzeczywistości (1973), znajdziemy taki zapis:

\footnotetext{
- daj spokój... nie lubię geografii...

- dlaczego?

- bo się wciąż zmienia

Lu. (Białoszewski 2013: 10).
} 
Krótkie, niemal aforystyczne zapisy, noszące pierwotnie wyrazisty i prowokujący podtytuł „protokoły z epoki”, są próbą oddania głosu innym. Rolą twórcy jest nasłuchiwanie, kolekcjonowanie, ale kiedy trzeba także dopytywanie, a wreszcie montowanie cytatów i opatrywanie ich didaskaliami. Można powiedzieć, że umieszczone na początku pierwszej współczesnej książki niepoetyckiej pisarza cykle Donosów i Cytatów to rodzaj programu-manifestu prozatorskiego, wskazanie, co będzie przedmiotem uwagi i jak to będzie przetwarzane. Antygeograficzny bon mot Lu. jest donosem rzeczywistości i protokołem z epoki, został wypowiedziany dzięki dopytaniu pisarza, zarejestrowany i wydany w kolekcji, wydobyta perła doczekała się autorskiej oprawy. Ludwik Hering, w prozie Białoszewskiego stale kryptonimowany jako Lu., urodził się w roku 1908, należał więc do osób, które partycypowały w obu wojennych zmianach kartograficznych, mających w przypadku Europy i Polski charakter całościowy. Jeśli „epoka” oznaczałaby tu powojenną rzeczywistość czy po prostu współczesność, to dodać należałoby jeszcze jedną wielką rewolucję na mapie politycznej świata, związaną z upadkiem systemu kolonialnego. Cytaty pochodzą najwyraźniej z różnych dekad, niewykluczone, że właściwym kontekstem dla dialogu autora z Lu. jest owa dynamika dekolonizacyjna. To też może być powód braku ingerencji cenzury, wyczulonej na mniej lub bardziej wyraziste aluzje historyczno-geograficzne do losów i trajektorii Polaków, zwłaszcza na Wschodzie (Sokołowska 2013: 259).

Z kolei Tadeusz Konwicki w jednym ze swoich pisanych na początku lat osiemdziesiątych łże-dzienników wskazuje w charakterystyczny dla siebie sposób na jeszcze jedną zmianę:

Za mego dzieciństwa w atlasach, z których uczyłem się geografii, były jeszcze białe plamy, dosłownie białe plamy śród czerwonawych pasm górskich i zielonych dolin nad niebieskimi rzekami. Każda baśń zaczynała się albo kończyła apostrofą do świata, który nie ma końca. (...) Nie mówiliśmy: ziemia. Bo ziemia to coś skończonego, ograniczonego, dosłownego. Ziemia to przyziemność. Mówiliśmy zawsze: świat. A słowo „świat” to przestrzenie, dale, tęsknoty i poezje (Konwicki 1990: 109).

I dodaje: tytuł powieści Juliusza Verne'a W 80 dni dookoła świata to była wielka prowokacja i bezczelność, tymczasem „statki kosmiczne obiegają kulę ziemską w półtorej godziny" (Konwicki 1990: 109). To jedna z ulubionych konstatacji pisarza. W Zaduszkach pojawia się motyw zainteresowania coraz bardziej szczegółowym obrazem Księżyca, jakiego miały dostarczyć wysłane tam sondy, a niemogący sobie poradzić z własną przeszłością bohater widzi na wystawie księgarni w prowincjonalnym miasteczku globus, wokół którego „toczy się świecący model sputnika”. Gdy jednak wróci do hoteliku, do czytającej gazetę na temat zdobywania kosmosu partnerki, dowie się od niej, że „nic nie ma na tym Księżycu” (Konwicki 1993: 135, 138). Bohater, dodajmy, grany przez Edmunda Fettinga, jednego z licznych polskich wykonawców pieśni A jednak mi żal 
Bułata Okudżawy o rakietach unoszących nas w dal w czasie, gdy „po Moskwie nie suną już sanie" (słowa polskie Witolda Dąbrowskiego). Tak. Z pewnością Konwicki nie był jedynym, który stwierdzał ówcześnie, że, jak to ujął Hłasko, „odlatujemy w niebo” z niezałatwionymi sprawami na ziemi. Skok w kosmos to jednak nie tylko kontrapunkt dla naszych problemów etycznych, oznacza on również rewolucję w mapowaniu Ziemi, i nie tylko Ziemi. W roku produkcji i premiery Zaduszek, czyli 1961, wyszedł po polsku (w rok po swojej radzieckiej publikacji) Atlas odwrotnej strony Księżyca, stanowiący próbę interpretacji fotografii zrobionych przez Łunę 3 w październiku 1959 roku - wydarzenie to, wraz z wydanymi na początku lat sześćdziesiątych atlasami fotograficznymi widocznej strony, zamyka symbolicznie określoną epokę w dziejach selenografii. Dwudziestowieczna zmiana przedstawień kartograficznych to nie tylko całkowite wypełnienie mapy fizycznej naszego globu, zastąpienie romantycznej ciekawości świata narzędziami pozwalającymi na jego całkowite kontrolowanie, ale również cywilizacyjnym projektem zdolnym dostarczyć coraz dokładniejszych obrazów wszechświata. Map ciał niebieskich na niewiele gorszym poziomie niż plany Ziemi.

Koniec kartograficznego świata to swego rodzaju topos, motyw obiegowy, mający w utworach i świadectwach różnorodne postaci. Istnieje jego odmiana sentymentalna, wskazująca nostalgicznie na bezpowrotnie utraconą epokę. Jan Twardowski rozpoczyna wiersz Na biurku z tomu Niebieskie okulary (1980) słowami:

\footnotetext{
Tu leży mapa co się zmienia

po każdej wojnie już nie taka sama

tam znaczki pocztowe znowu trochę inne

klej niby farba rozpuszczona w wodzie

(Twardowski 2002: 125).
}

W dalszym ciągu podmiot liryczny opisuje rzeczy znajdujące się na i w biurku (najpewniej swoim), które mogłoby być muzealnym eksponatem w izbie pamięci. Mebel jest świadkiem nie tylko przeszłości właściciela, ale także jego mentalnego przebywania w minionej rzeczywistości, zgodnego z maksymą, że "tylko serce odmierza czas w odwrotną stronę" (tamże, wers 12), na co wskazują pamiętnik jakiejś damy, stary pieniądz, który wyszedł z obiegu czy fotografie zmarłych. Nawet zwykłe przedmioty użytkowe rozpatruje się tutaj w kontekście upływającego czasu, który sprawia, że stają się bezużyteczne. Mapa jest właśnie jedną z takich ulegających przedawnieniu rzeczy, podobnie jak znaczki czy zastąpione przez długopisy - nomen omen - wieczne pióro. Można chyba nawet powiedzieć, iż wojenna zmienność mapy jest tu jej cechą niemal immanentną, definicyjną, nietrwałość przynależy do jej istoty, ale w walucie serca wartość takiej mapy po zmianie może urosnąć.

Zresztą radykalna zmiana świata może ujawnić wzrost kursu mapy w całkiem wymiernym sensie finansowym. I bynajmniej nie chodzi tylko o obieg antykwaryczny. 
Sytuacja braku może nieoczekiwanie ujawnić popyt na kartografię jako materiał, co poniekąd widzieliśmy w przypadku historii bawełnianej surówki z Rajzy Białoszewskiego. Podobny los spotkał przygotowane przez Sekcję Geograficzną KGAK "Schronisko", o której działalności już pisałem, mapy ze składnicy położonej na ulicy Krochmalnej 9. Materiały kartograficzne leżały do końca wojny w piwnicach mieszczącej się pod tym adresem wytwórni prefabrykatów budowlanych w stanie nienaruszonym, gdzie - wedle świadectwa zastępcy szefa „Schroniska” Edwarda Rühlego - „w maju i czerwcu [1945] «szabrownicy» ją odkopali, a całą zawartość jako makulaturę do pakowania sprzedali straganiarzom w hali targowej przy ulicy Koszykowej" (Rühle 1982: 168). Część materiałów udało się Rühlemu, który natknął się przypadkowo na mapy w tej nowej dla nich roli, odzyskać poprzez zamianę na papier pakowy i wykup. Szczęśliwym zbiegiem okoliczności było też funkcjonowanie dobrze zamaskowanego magazynu w tym miejscu - kamienica pod numerem 9 w całym dużym kwartale zabudowy Grzybowska - Ciepła - Krochmalna - Rynkowa, jako jedna z pięciu (na Krochmalnej jedyna), zachowała się w stopniu umożliwiającym zamieszkiwanie zaraz po wojnie 3 . Z kolei papier w pierwszych miesiącach po wojnie był towarem szczególnie deficytowym, o czym świadczą inwentaryzacje i lustracje przeprowadzane przez pracowników rzeczonego biura "na jakimkolwiek dostępnym papierze, często na papierze firmowym przedwojennych przedsiębiorstw" (Zadrożniak, Aleksiejuk 2011: 32).

Mapy więc u końca wojny przybierają również, tak jak u jej początków, swoją postać ultramaterialną i czysto przedmiotową, stając się etykietą zastępczą i dołączając do anegdotycznego kręgu śledzi opakowanych w inkunabułowe cymelia. Wyjście z obiegu praktycznego i przejście do obiegów innych: antykwarycznego, historycznego, upamiętniającego, ale też makulaturowo-recyklingowego zmienia repertuar praktyk, jakim podlega dana mapa, wywołuje zdziwienie, wzruszenie. Radykalna zmiana rzeczywistości, jaką jest wojna, ujawnia konstrukcję świata w sposób, co zrozumiałe, znacznie bardziej nagły niż w przypadku procesów rozłożonych w czasie czy narastających ewolucyjnie, o których również wspomniałem. Warta podkreślenia jest tu nieco uprzywilejowana rola pisarza w dekonstruowaniu mapy. Główną jego zaletą zdaje się przede wszystkim łatwa produkcja świadectw - literatura jest po prostu rezerwuarem różnorodnej problematyki, w tym także tej dotyczącej kartografii. Czuli na szczegóły realistyczne czy urodę plastyczną ludzie pióra po prostu zwrócą na ten przedmiot baczniejszą uwagę. Jako przedstawiciel kasty intelektualnej miewa także często pisarz analityczną czujność. Twórczość Mirona Białoszewskiego zda się jednak wyjątkiem o tyle, że mamy do czynienia z osobą zarówno zainteresowaną codziennymi zdarzeniami, jak i obdarzoną oryginalnym spojrzeniem, skłonną

3 Mimo braku dachu w sierpniu 1945 r. mieszkało w bocznej i tylnej oficynie 100 osób, o czym informował Ilustrator Biura Odbudowy Stolicy (https://www.szukajwarchiwach.gov.pl/jednostka/-/ jednostka/12452361). 
do wywiedzenia z repertuaru najbardziej banalnych praktyk tkwiących w nich nieoczywistości. Ten splot cech sprawia, że jego znalezienie się w awangardzie dekonstrukcji kartograficznej było poniekąd nieuniknione. Trzeba tu dodać, że inicjujący nurt krytycznej rewizji w historii i teorii kartografii artykuł J.B. Harleya Deconstructing the Map z 1989 roku, opierał się na rozliczeniu z ideą mapy rozumianej jako konstrukt oświeceniowo-racjonalistycznego umysłu (Harley 1989). Autor budował dla świata map analogię ze światem tekstów i dyskursów oraz szukał sojuszników w całej gromadzie ważnych dla humanistyki drugiej połowy XX wieku nazwisk, aczkolwiek głównymi patronami rozgrywki z zachodnią kartografią w poszczególnych częściach tekstu byli Michel Foucault (część pierwsza poświęcona uprawomocnieniu się naukowego dyskursu kartograficznego i jego oddziaływaniu, trzecia - społecznemu wymiarowi map i ich roli w podtrzymywaniu władzy) i Jacques Derrida (część druga dotycząca retorycznego wymiaru map). Wybitny historyk kartografii, Harley, w mniejszym stopniu zwracał uwagę na przykłady z dziejów rozumienia i posługiwania się mapą, a już zwłaszcza niekonwencjonalnego jej czytania, oraz ważny przecież dla dekonstrukcjonistów koncept odczytania jako niedoczytania (Nycz 2000: 11). W ujęciu autora mapa była wytworem nowoczesnego rozumu kartograficznego, który należy zdekonstruować. Brakowało w tym podejściu miejsca na ironię użytkownika, nie było takiej możliwości, by ktoś już na konkretnym materiale dawno posłał ten rozum do diabła. Niedowartościowanie sfery pragmatycznej było więc głównym mankamentem projektu krytyki kartograficznej. Późniejsze prace powstałe w nurcie kartografii krytycznej (mam tu na myśli przede wszystkim amerykańskich geografów urodzonych w latach 40.: Denisa Cosgrove'a, Marka Monmoniera i Denisa Wooda; z młodszych badaczy do tej nazwy i osiągnięć starszych przedstawicieli nawiązują Jeremy Crampton i John Krygier) kontynuowały w jakiejś mierze ten projekt, jednakże z czasem pojawił się komponent badań pragmatyki kartograficznej, ale przedstawiciele tego nurtu docenili przede wszystkim wagę twórczości artystycznej(Crampton, Krygier 2005: 17-19); krytyka kartografii była z kolei krytykowana za niedocenienie taktyk oporu przeciw zachodniemu modelowi, jakimi posługiwali się przedstawiciele nieeuropejskich kultur (Bender 2014: 263-264).

Tymczasem przywoływane w tekście świadectwa dobrze pokazują, że motorem dekonstrukcji kartografii są konkretne zdarzenia, jakie przytrafiają się użytkownikom i samym mapom. Efekt obcości i potrzebę namysłu nad nimi może przynieść ich nieprzydatność praktyczna, ale także nieoczekiwana przydatność wbrew przeznaczeniu, jak również dysonans poznawczy - znalezienie się ich w kontekście niespodziewanym, groteskowym, symbolicznym. Wojna jest katalizatorem tego dystansu, zatem i dekonstrukcji. 


\section{Bibliografia}

Barthes, R. (1996). Światło obrazu. Uwagi o fotografii (przeł. J. Trznadel). Warszawa: Wydawnictwo KR.

Bender, B. (2014). Odrzucając Zachodnie Spojrzenie: kreślenie map światów alternatywnych (przeł. M. Gimbut). W: B. Frydryczak, D. Angutek (red.), Krajobrazy. Antologia tekstów (s. 255-270). Poznań: Wyd. Poznańskiego Towarzystwa Przyjaciół Nauk.

Białoszewski, M. (2013). Donosy rzeczywistości. Warszawa: PIW.

Białoszewski, M. (2014a). Szumy, zlepy, ciągi. Warszawa: PIW.

Białoszewski, M.(2014b). Pamiętnik z powstania warszawskiego. Warszawa: PIW.

Białoszewski, M. (2015). Proza stojąca, proza lecąca. Teksty rozproszone i niepublikowane. Warszawa: PIW.

Crampton, J.W., Krygier J. (2005). An Introduction to Critical Geography. ACME. An International E-Journal for Critical Geographies, 4(1), 11-33.

Franz, M. (2011). W pogoni za „Źółtym Tygrysem”. Studia z Dziejów Polskiej Historiografii Wojskowej. T.12.

Gómez de la Serna, M. (1979). Myśli rozbrykane (przeł. J. Strasburger). Warszawa: Państwowy Instytut Wydawniczy.

Harley, J.B. (1989). Deconstructing the Map. Cartographica, 26(2), 1-20.

Hłasko, M. (2016). Najlepsze lata naszego życia. Warszawa: Wydawnictwo Iskry.

Ilustrator Biura Odbudowy Stolicy. Pozyskano z: https://www.szukajwarchiwach.gov.pl/jednostka/-/ jednostka/12452361.

Kiersnowski, R. (2007). Tam i wtedy. W Podweryszkach, w Wilnie i w puszczy 1939-1945. Warszawa: Instytut Historii PAN.

Konrad, A. (1963). Akcja „Plan Warszawy”. Warszawa: Wydawnictwo MON.

Konwicki, T. (1990). Wschody i zachody księżyca. Warszawa: OW Interim.

Konwicki, T. (1992). Rojsty. Warszawa: Wydawnictwo NOW.

Konwicki, T. (1993). Ostatni dzień lata. Scenariusze filmowe. Warszawa: Kwiaty na Tor

Krassowski, B. (1981). „Schronisko”. Służba Geograficzna Armii Krajowej. Warszawa: Biblioteka Narodowa.

Mędrzecki W. (1995). Przemiany cywilizacyjne i socjotopograficzne miast województwa wołyńskiego 1921-1939. Kwartalnik Historii Kultury Materialnej, 1, 107-113.

Mędrzecki, W. (2018). Kresowy kalejdoskop. Wędrówki przez ziemie wschodnie Drugiej Rzeczypospolitej 1918-1939. Kraków: Wydawnictwo Literackie.

Narodowe Archiwum Cyfrowe - Mapa Europy i mapy półkul przekazane do szkół. Pozyskano z: https:// audiovis.nac.gov.pl//obraz/102332/4437ad177c1679b1090c78835bb6c221/.

Narodowe Archiwum Cyfrowe - Szkoła podstawowa w Kalenicach. Pozyskano z: https://audiovis.nac. gov.pl/obraz/193710/ebdb60f20f72c3107c779193acf6b141/.

Narodowe Archiwum Cyfrowe - Uczennice szkoły powszechnej w Zdołbunowie. Pozyskano z: https:// audiovis.nac.gov.pl/obraz/105193/585062392a16cd0a50d9f1dde0bc0881.

Narodowe Archiwum Cyfrowe - Uczniowie szkoły powszechnej dla dzieci huculskich w Żabiu. Pozyskano z: https://audiovis.nac.gov.pl/obraz/105223/e666107ca935d27c04ff677e1b6e875e/.

Narodowe Archiwum Cyfrowe - Wystawa historyczna. Na ścianie wisi mapa wykonana przez uczniów przedstawiająca bitwę pod Wiedniem. Pozyskano z: https://audiovis.nac.gov.pl/obraz/107745/4437ad177c1679b1090c78835bb6c221/. 
Naumienko, T. (1978). Gwardia Ludowa, Armia Ludowa. W: B. Dzikiewicz, B. Krassowski, T. Naumienko (red.), Prace polskich topografów wojskowych w czasie II wojny światowej (Wspomnienia i refleksje) (s. 32-33). Warszawa: Wydawnictwo Czasopism Technicznych NOT.

Nycz, R. (2000). Dekonstrukcja w badaniach literackich. Gdańsk: słowo/obraz terytoria.

Twardowski, J. (2002). Na biurku. W: A. Iwanowska (red.), Wiersze z tomów z lat 1979-1980 (s.125) Kraków: Wydawnictwo „M”.

Pruszyński, K. (2000). Podróż po Polsce. Warszawa: Czytelnik.

Rodak, P. (2009). Niecodzienna codzienność czasu okupacji. „Znak”, 9(652), 38-52.

Rühle, E. (1980). Polskie konspiracyjne wydawnictwa kartograficzne w okresie okupacji hitlerowskiej. „Polski Przegląd Kartograficzny”, 4, 168-175

Sobczak, K. (2017). Śnieg, las, mus. W: A. Karpowicz, P. Kubkowski, W. Pessel, I. Piotrowski (red.), Ułamek błękitu i chmur. Warszawa Tadeusza Konwickiego (s. 26-41). Warszawa: Lampa i Iskra Boża.

Sobczyński, E. (2000). Historia Służby Geograficznej i Topograficznej Wojska Polskiego. Warszawa: Wydawnictwo Bellona.

Sobczyński, E. (2009). Wojskowy Instytut Geograficzny w wojnie obronnej 1939 r. Geodeta (dodatek „Historia"), 9

Sokołowska, M. (2013). Nota od wydawcy. W: M. Białoszewski, Donosy rzeczywistości (s. 257-263). Warszawa: Państwowy Instytut Wydawniczy.

Sokołowska, M. (2015). Źródła tekstów. Uwagi. W: M. Białoszewski, Proza stojąca, proza lecąca. Teksty rozproszone i niepublikowane (s. 405-420). Warszawa: Państwowy Instytut Wydawniczy.

Szalewska, K. (2017). Urbanalia - miasto i jego teksty. Humanistyczne studia miejskie. Gdańsk: słowo/ obraz terytoria.

Ważyk, A. (1956). Mity rodzinne. Warszawa: Wydawnictwo Czytelnik.

Wernik, R. (2001). W Zdołbunowie zakwitły kaczeńce. Biały Dunajec-Ostróg: „Wołanie z Wołynia”.

Wieczorkiewicz, B. (1966). Gwara warszawska XIX wieku. Warszawa: PWN.

Wyka, K. (2011). Życie na niby. Kraków: Wydawnictwo Universitas.

Zadrożniak, A., Aleksiejuk, M. (2011). Rola i zadania Wydziału Inwentaryzacji i Statystyki Biura Odbudowy Stolicy. W: Archiwum Biura Odbudowy Stolicy. Warszawa: Stowarzyszenie Przyjaciół Archiwum Państwowego m.st. Warszawy/APW m. st. Warszawy.

\section{Streszczenie}

Artykuł dotyczy funkcjonowania map i ich wyobrażeń w warunkach wojennych na przykładzie polskiego materiału dotyczącego II wojny światowej. Punktem wyjścia jest relacja Mirona Białoszewskiego zawarta w opowiadaniu Rajza dotycząca ucieczki jego rodziny we wrześniu 1939 roku w stronę granicy wschodniej. Opowiadanie wprowadza wątki, które są obecne w innych tekstach okołowojennych i powojennych autora Pamiętnika z powstania warszawskiego, i które są interpretowane w kontekście innych źródeł (przede wszystkim literackich). Mapy używane podczas wojny miały wymiar propagandowy, dezorientowały zarówno swoich, jak i obcych użytkowników (czytelników). Okres wojenny oznacza ciągłe zapotrzebowanie na mapy oraz ujawnia deficyt przestawień kartograficznych, a jednocześnie ciągle zmieniająca się rzeczywistość obnaża ich bezużyteczność, w skrajnych przypadkach sprowadzając je do surowca wtórnego. Wojna jest stanem wyjątkowym, w którym proces dekonstrukcji kartografii zostaje przyśpieszony. Jest to więc moment, w którym postulaty nurtu krytycznego w historii i teorii kartografii 
zostają spełnione, a pragmatyka dowartościowana. To użytkownik w konkretnej sytuacji dokonuje demaskacji racjonalnego umysłu stojącego za kartografią.

Słowa klucze: kartografia wojenna, dekonstrukcja mapy, II wojna światowa, Miron Białoszewski, pragmatyka

\section{Summary}

The paper concerns the topic of maps, functioning of maps and concepts of maps in the wartime conditions on the example of polish sources on Second World War. My point of departure is Miron Białoszewski's account, as contained in his short story Rajza, of his family's escape towards the Eastern border in September 1939. The story introduces many motifs, which are present in Białoszewski's other texts concerning the war, and which are interpreted in the context of other sources (mostly literary sources). Maps used during the war had a propagandistic character; they confused their readers, allies and enemies alike. A wartime period results in a constant need for maps, but also in a shortfall of cartographic representations. At the same time, an ever-changing reality exposes their worthlessness and, in the most extreme cases reduces them to secondary raw material. War is an extraordinary state, in which the process of deconstruction of cartography is accelerated. In this way, the criteria of critical currents in the theory and history of cartography are fulfilled. However, this deconstruction brings about the appreciation of its pragmatic aspect: it is the reader who, in specific circumstances, can expose the rational mind behind cartography.

Keywords: war cartography, deconstruction of the map, Second World War, Miron Białoszewski, pragmatics 
